\title{
Studi Kasus: Asuhan Keperwatan Jiwa Pada Tn.B Dengan Risiko Perilaku Kekerasan
}

\author{
Hilyati Husna
}

Hilyatihusna.24@gmail.com

\author{
BAB 1 \\ PENDAHULUAN
}

\subsection{LATAR BELAKANG}

Skizofrenia merupakan penyakit kronis, parah, dan melumpuhkan, gangguan otak yang di tandai dengan pikiran kacau, waham, delusi, halusinasi, dan perilaku aneh atau katatonik (Pardede \& Laia, 2020). Skizofrenia merupakan suatu gangguan jiwa berat yang bersifat berat dan kronis yang menyerang 20 juta orang di seluruh dunia (WHO, 2019). Skizofrenia menimbulkan distorsi pikiran, distorsi persepsi, emosi, dan tingkah laku sehingga pasien dengan skizofrenia memiliki resiko lebih tinggi berperilaku agresif dimana perubahan perilaku secara dramatis terjadi dalam beberapa hari atau minggu. Pasien skizoprenia sering dikaitkan dengan perilaku kekerasan yang dapat membahayakan diri sendiri maupun orang lain ataupun berisiko juga dengan lingkungan sekitarnya, baik secara fisik, emosional, seksual, dan verbal (Baradero, 2016; Sutejo,2018).

Skizofrenia merupakan suatu gangguan jiwa berat yang bersifat kronis yang ditandai dengan ganggguan komunikasi, gangguan realitas, resiko perilaku kekerasan, afek tidak wajar atau tumpul, gangguan fungsi kognitif serta mengalami kesulitan dalam melakukan aktivitas sehari-hari (Pardede, 2020). Risiko perilaku kekerasan merupakan salah satu respon marah diekspresikan dengan melakukan ancaman, mencederai diri sendiri maupun orang lain dan dapat merusak lingkangan sekitar. Tanda dan gejala risiko perilaku kekerasan dapat 
terjadi perubahan pada fungsi kognitif, afektif, fisiologis, perilaku dan social. Pada aspek fisik tekanan darah meningkat denyut nadi dan pernapasan meningkat mudah tersinggung, marah, amuk serta dapat mencederai diri sendiri maupun orang lain (Keliat \& Muhith, 2016).

Menurut Afnuhazi (2015), faktor predisposisi yang menyebabkan perilaku kekerasan antara lain, psikologis, perilaku, sosial budaya, dan bioneurologis. Sedangkan untuk faktor presipitasi itu sendiri dapat bersumber dari klien, lingkungan dan interaksi dengan orang lain. Penyebab dari perilaku kekerasan yaitu seperti kelemahan fisik (penyakit fisik), keputusasaan, ketidakberdayaan, dan kurang percaya diri. Untuk faktor penyebab dari perilaku kekerasan yang lain seperti situasi lingkungan yang terbiasa dengan kebisingan, padat, interaksi sosial yang proaktif, kritikan yang mengarah pada penghinaan, dan kehilangan orang yang di cintai (pekerjaan) (Suryenti dkk, 2018 ). Menurut Dermawan \& Rusdi (2015), pasien yang mengalami resiko perilaku kekerasan adalah orang yang mempunyai tujuan utuk melukai seseorang, baik secara fisik maupun psikologis perilaku kekerasan dapat terjadi secara verbal, diarahkan pada diri sendiri, orang lain dan lingkungan.

Penderita skizofrenia yang sembuh dikembalikan kepada keluarga untuk dirawat dirumah. Keluarga adalah orang yang dekat dengan pasien harus bertanggung jawab dalam merawat pasien, namun dalam pelaksanaannyahal ini menjadi beban bagi keluarga. Keadaan ini meningkatkan stres dalam keluarga (Manao \& Pardede, 2019). Survei awal dilakukan di Yayasan Pemenang Jiwa Sumatera dengan jumlah pasien 70 orang tetapi yang menjadi subjek di dalam pembuatan askep ini berjumlah 1 orang dengan pasien masalah Resiko Perilaku Kekerasan atas nama inisial Tn.B, penyebabnya Tn.B. sebagai subjek di karenakan Klien belum bisa mengatasi Resiko Perilaku Kekerasan selain minum obat. Maka tujuan asuhan keperawatan yang akan di lakukan ialah untuk mengajarkan standar pelaksanaan masalah Resiko Perilaku Kekerasan pada saat Tn. B mengalami Resiko Perilaku Kekerasan.

\subsection{Rumusan Masalah}


Berdasarkan masalah yang telah didapat dilator belakang maka rumusan masalah dalam askep ini yaitu : Asuhan Keperawatan jiwa Pada Tn.B Dengan Gangguan Risiko Perilaku Diyayasan Pemenang Jiwa Sumatera

\subsection{Tujuan}

\subsubsection{Tujuan Umum}

Mahasiswa mampu memberikan Asuhan Keperawatan Jiwa Pada Tn.B dengan Gangan Risiko Perilaku Kekerasan.

\subsubsection{Tujuan Khusus}

1. Mahasiswa mampu mengetahui defenisi, tanda \& gejala, faktor penyebab, mekanisme koping, penatalaksanaanpada Klien dengan Risiko Perilaku Kekerasan.

2. Mahasiswa mampu melakukan pengkajian pada Klien dengan Risiko Perilaku Kekerasan

3. Mahasiswa mampu menegakkan diagnosa atau masalah keperawatan pada Tn. B dengan Risiko Perilaku Kekerasan.

4. Mampu menetapkan intervensi keperawatan secara menyeluruh pada Tn.B dengan Risiko Perilaku Kekerasan.

5. Mahasiswa mampu melakukan tindakan keperawatan yang nyata pada Tn.B dengan Risiko Perilaku Kekerasan.

6. Mahasiswa mampu mengevaluasi sebagai tolak ukur guna menerapkan asuhan keperawatan pada Tn. B dengan Risiko Perilaku Kekerasan.

7. Mahasiswa mampu mendokumentasikan asuhan keperawatan pada Tn.B dengan Risiko Perilaku Kekerasan.

\subsection{Manfaat}

1. Pasien

Diharapkan Tindakan yang telah diajarkan dapat di terapkan secara mandiri untuk bisa mengontrol resiko perilaku kekerasan untuk mendukung kelangsungan kesehatan pasien. 
2. Bagi Yayasan Pemenang Jiwa Sumatera

Diharapkan dapat menjadi acuan dalam menangani atau dalammemberikan pelayanan kepeada pasian gangguan jiwa dengan Risiko perilaku kekerasan di Yayasan Pemenang Jiwa. 


\section{BAB 2 \\ TINJAUAN TEORITIS}

\subsection{Konsep Perilaku Kekerasan}

\subsubsection{Pengertian}

Risiko perilaku kekerasan adalah suatu bentuk perilaku yang bertujuan untuk melukai seseorang, baik secara fisik maupun psikologis. Perilaku kekerasan dapat di lakukan secara verbal yang di arahkan pada diri sendiri, orang lain, dan lingkungan (Sutejo,2017). Perilaku kekerasan merupakan perilaku seseorang yang menunjukkan bahwa ia dapat membahayakan diri sendiri atau orang lain atau lingkungan, baik secara fisik, emosional, seksual, dan verbal.

Perilaku kekerasan merupakan bagian dari rentang respon marah yang paling maladaptif, yaitu amuk. Marah merupakan perasaan jengkel yang timbul sebagai respons terhadap kecemasan yang dirasakan sebagai ancaman individu. Amuk merupakan respons kemarahan yang paling maladaptif yang ditandai dengan perasaan marah dan bermusuhan yang kuat disertai hilangnya kontrol yang individu dapat merusak diri sendiri, orang lain atau lingkungan (Yusuf dkk, 2015).

\subsubsection{Tanda Dan Gejala Risiko Perilaku Kekerasan}

Menurut Pardede,.(2020) Tanda dan gejala dengan perilaku yang ditampilkan

Data Subjektif :
a) Mengungkapkan perasaan kesal atau marah
b) Keinginan untuk melukai diri sendiri,orang lain dan lingkungan
c) Klien suka membentak dan menyerang orang lain

Data Objektif :

a) Mata melotot/ pandangan tajam

b) Tangan mengepal dan Rahang mengatup 

c) Wajah memerah
d) Postur tubuh kaku
e) Bicara kasar, ketus
f) Amuk/agresif
g) Menyerang orang lain dan Melukai diri sendiri/ oranglain.

\subsubsection{Etilogi}

Penyebab dari perilaku kekerasan yaitu seperti kelemahan fisik (Penyebab fisik),keputusasaan ,ketidak berdayaan,dan kurang percaya diri.Untuk factor penyebab dari perilaku kekerasan yang lain seperti situasi lingkungan yang terbiasa dengan kebisingan ,padat ,interaksi social yang proaktif,kritikan yang mengarah pada penghinaan ,dan kehilangan orang yang dicintai (pekerjaan).Marah merupakan perasaan jengkel yang timbul sebagai respon terhadap kecemasan(kebutuhan yang tidak terpenuhi) yang dirasakan sebagai ancaman (Putri,Mella \&Fitriani,2018).

Faktor predisposisi yang menyebabkan perilaku kekerasan antara lain,psikologis,perilaku,social budaya ,dan bioneurologis.Sedangkan untuk factor presipitasi itu sendiri dapat bersumber dari klien,lingkungan dan interaksi dengan orang lain.Penyebab dari perilaku kekerasan yaitu seperti kelemahan fisik (penyakit fisik).keputusasaan,ketidak berdayaan,dan kurng percaya diri (Putri,Mella \&Fitriani,2018).

\subsubsection{Rentang Respon Marah}

Adaptif

Maladaptif

Asertif Frustasi Pasif Agresif Amuk

\section{Gambar 2.1 Rentang Respon Marah}

Keterangan :

\section{Respon Adaptif}

a. Asertif : Individu dapat mengungkapkan marah tanpa 
menyalahkan orang lain dan memberikan ketenangan

b. Frustasi : Individu gagal mencapai tujuan kepuasan saat marah dan tidak dapat menemukan alternative (Mulia, 2020).

\section{Respon Maladaptif}

a. Pasif : Individu tidak dapat mengungkapkan perasaan nya.

b. Agresif : Perilaku yang menyertai marah, terdapat dorongan untuk menuntut tetapi masih terkontrol.

c. Kekerasan : Perasaan marah dan bermusuhan yang kuat serta hilang nya control (Mulia, 2020)

\subsubsection{Perilaku Risiko Kekerasan}

Menurut Sutejo (2017)gangguan perilaku kekerasan memiliki beberapa perilaku yang perlu di perhatikan. Perilaku klien dengan gangguan perilaku kekerasan dapat membahayakan bagi dirinya sendiri, orang lain, maupun lingkungan sekitar, adapun perilaku yang harus di kenali dari klien gangguan risiko perilaku kekerasan, antara lain:

a. Menyerang atau menghindari

Pada keadaan ini respon fisiologis timbul karena kegiatan system syaraf otonom bereaksi terhadap sekresi ephineprin yang menyebabkan tekanan darah meningkat, takikardi, wajah merah, pupil melebar, mual, sekresi HCL meningkat, peristaltik gaster menurun, pengeluaran urine dan saliva meningkat, konstipasi, kewaspadaan meningkat, disertai ketegangan otot seperti; rahang terkatup, tangan mengepal, tubuh menjadi kaku dan disertai reflek yang cepat.

b. Menyatakan secara asertif

Perilaku yang sering di tampilkan individu dalan mengekspresi kemarahannya, yaitu perilaku pasif, agresif, dan asertif. Perilaku aseertif merupakan cara terbaik individu untuk mengekspresikan rasa marahnya tanpa menyakiti orang lain secara fisik maupun psikologis. Dengan perilaku tersebut, individu juga dapat mengembangkan diri.

c. Memberontak Perilaku yang muncul biasanya disertai kekerasan akibat konflik perilaku untuk menarik perhatian orang lain,Perilaku kekerasan 
Tindakan kekerasan atau amuk yang di tujukan kepada diri sendiri, orang lain, maupun lingkungan.

\subsubsection{Penatalaksanaan}

Penanganan yang dilakukan untuk mengontrol perilaku kekerasan yaitu dengan cara medis dan non medis. Terapi medis yang dapat di berikan kepada pasien yaitu Haloperidol 5 mg (2x1), Trihexyphenidyl 2 mg (2x1), Risperidone $2 \mathrm{mg}(2 \times 1)$, dan Chlorpromazine $1 \mathrm{mg}$ (1x1) (Silvia \& Kartina, 2020). Untuk terapi non medis seperti terapi generalis, untuk mengenal masalah perilaku kekerasan serta mengajarkan pengendalian amarah kekerasan secara fisik : nafas dalam dan pukul bantal, minum obat secara teratur, berkomunikasi verbal dengan baik-baik, spritual : beribadah sesuai keyakinan pasien dan terapi aktivitas kelompok, (Hastuti, Agustina, \& Widiyatmoko 2019).

\subsection{Konsep Asuhan Keperawatan}

\subsubsection{Pengkajian}

\subsubsection{Pengkajian Keperawatan}

Pengkajian adalah sebagai dasar utama dari proses keperawatan. Tahap pengkajian terdiri dari pengumpulan data dan perumusan masalah klien. Data yang dikumpulkan melalui data biologis, psikologis, sosial dan spiritual (Saputri \& Mar’atus, 2021)

Analisa Data Dengan melihat data subyektif dan objektif dapat menentukan permasalahan yang dihadapi pasien. Dan dengan memperhatikan pohon masalah dapat diketahui penyebab, affeck dari masalah tersebut. Dari 12 hasil analisa data inilah dapat ditentukan diagnosa keperawatan (Hasannah, 2019).

\subsubsection{Diagnosa Keperawatan}

Diagonsa Keperawatan ialah identifikasi atau penilaian Daignosa keperawatan ialaqh identifikasi atau penilaian terhadap pola respon pasien baik secara actual maupun potensial dan merupakan dasar pemilihan intervensi dalam mencapai tujuan yang telah ditetapkan 
oleh perawat yang bertanggung jwaba (Muhith, 2015).

\subsubsection{Intervensi Keperawatan}

Intervensi pada pasien dengan risiko perilaku kekerasan dapat dilakukan dengan pemberian teknik mengontrol perilaku kekerasan dengan pemberian SP I cara fisik yaitu relaksasi tarik nafas dalam serta penyaluran energi, SP II dengan pemberian obat, SP III verbal atau social, SP IV spiritual. Intervensi tersebut dilakukan kepada pasien lalu pasien diberikan jadwal kegiatan sehari dalam upaya mengevaluasi kemampuan pasien mengontrol perilaku kekerasan pasien (Hasannah, 2019).

\subsubsection{Implementasi Keperawatan}

Implementasi adalah tahapan ketika perawat mengaplikasikan ke dalam bentuk intervensi keperawatan guna membantu klien mencapai tujuan yang telah di tetapkan. Kemampuan yang harus dimiliki oleh perawat pada tahap implementasi adalah kemampuan komunikasi yang efektif, kemampuan utnuk menciptakan saling percaya dan saling membantu, kemampuan melakukan teknik, psikomotor, kemampuan melakukan observasi sistemis, kemampuan memberikan pendidikan kesehatan, kemampuan advokasi dan kemampuan evaluasi (Anggit, 2021).

\subsubsection{Evaluasi Keperawatan}

Evaluasi Keperawatan merupakan proses yang berkelanjutan untuk menilai efek dari tindakan keperawatan pada pasien. Evaluasi dilakukan dengan pendekatan SOAP sebagai berikut, S : Respon

subjektif pasien terhadap tindakan keperawatan yang telah dilaksanakan, $\mathrm{O}$ : Respon objektif pasien terhadap tindakan keperawatan yang telah dilaksanakan, A:Analisis terhadap data subjektif dan objektif untuk menyimpulkan apakah masalah masih tetap ada, muncul masalah baru, atau ada data yang kontradiksi 
terhadap masalah yang ada, dan $\mathrm{P}$ : Tindak lanjut berdasarkan hasil analisis respon pasien rencana tindak lanjut dapat berupa hal rencana dilanjutkan (jika masalah tidak berubah) atau rencana dimodifikasi (jika masalah tetap, sudah dilaksanakan semua tindakan terapi hasil belum memuasakan) (Anggit, 2021). 


\subsection{Identitas Klien}

\section{BAB 3 \\ TINJAUAN KASUS}

Inisial

Ruang Rawat

Tanggal Pengkajian

Umur

Agama

Status

Informant
: Tn.B

: Yayasan pemenang jiwa sumatera utara

: 3 Maret 2021

: 39 Tahun

: Islam

: Duda

: Klien

\subsection{Alasan Masuk}

Klien Awalnya di jalan dan sering melamun ,marah-marah karena kesal, sering bicara sendiri, mondar mandir, mendengar suara-suara tanpa wujud, tertawa sendiri,memukul orang.

\subsection{Faktor Predisposisi}

Klien sebelumnya belum pernah mengalami gangguan jiwa. Awalnya klien menikah dengan janda anak 2 setelah menikah beberapa tahun klien diceraikan oleh istrinya dan klien tinggal disuatu kos didaerah marelan klien di tipu oleh teman sendiri dan uang klien dibawa kabur.Dari situ klien tinggal dijalanan sering melamun marah-marah karena kesal dan mendengar suara tanpa wujud. Akhirnya ada orang yang membawanya ke Yayasan Pemenang Jiwa Provinsi Sumatera karena ibu tersebut tidak tega melihatnya karena ibu tersebut sering memberikan makan pagi,siang dan malam, akhirnya klen dibawa oleh ibu tersebut pada tahun 2019 .

\subsection{Fisik}

Klien tidak memiliki keluhan fisik, saat dilakukan pemeriksaan tanda-tanda vital, didapatkan hasil TD : 120/80 mmHg ; $\mathrm{N}: 81 \mathrm{x} / \mathrm{i} ; \mathrm{S}: 36,5^{\circ} \mathrm{C} ; \mathrm{P}: 21 \mathrm{x} / \mathrm{i}$. Klien memiliki tinggi badan $165 \mathrm{~cm}$ dan berat badan $69 \mathrm{Kg}$.

\subsection{Psikososial}


3.3.1.Genogram

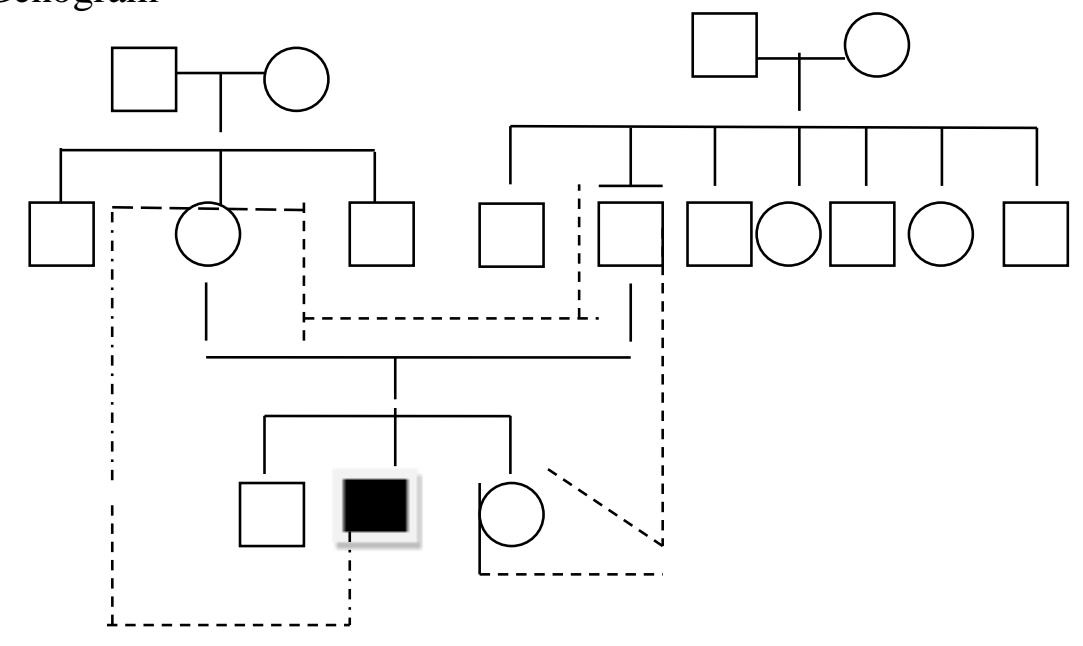

$\square$ Laki-laki $\square_{\text {Perempuan }}$

---- : Tinggal dalam satu rumah

$\triangle$ meninggal

Keterangan : Klien adalah anak ke dua dari 3 saudara, sudah menikah, jauh dari keluarga

\subsubsection{Konsep diri}

1. Gambaran diri : Tidak ada kecacatan

2.Identitas : Klien anak ke 2 dari 3 bersaudara., yang saat ini dirawat di yayasan pemenang jiwa sumatera

3.Peran : Klien hanya lulusan SMA yang saat ini

memiliki pekerjaan setelah klien ditipu oleh temansendiri

4.Ideal diri : Klien merasa malu karena di antarkan ke yayasan pemenangan jiwa tersebut.

5.Harga diri : Klien merasa apakah dirinya tidak dianggap oleh saudara nya lagi semenjak

Masalah keperawatan: Gangguan konsep diri : Harga diri rendah 


\subsubsection{Hubungan Sosial}

1) Orang yang berarti : keluarganya adalah orang - orang yang berarti dalam hidup klen.

2) Serta dalam kegiatan kelompok / masyarakat : pasien mengatakan sebelum sakit selalu dekat dengan teman dan mengikuti kegiatan dimasyarakat.

3) Hambatan dalam berhubungan dengan orang lain : Klien mengatakan bicara hanya bila perlu, memendam masalah sendiri dan tidak bercerita dengan orang terdekat. Klien terkadang acuh pada lawan bicara.

\subsubsection{Spiritual}

1) Nilai dan keyakinan : pasien beragama Islam, percaya dan pasrah kepada Allah SWT, yakin bahwa semua sudah diatur. Pasien ingin pulang ke rumah dan berharap keluarga dan masyarakat mau menerima keadaanya. Pasien mengatakan ingin berusaha memperbaiki diri dan tidak menyakiti orang orang disekitanya lagi.

2) Kegiatan ibadah : pasien mengatakan selalu sholat lima waktu.

\subsubsection{Status Mental}

\section{a. Penampilan}

Penjelasan : Klien berpenampilan bersih, dan rapi

b. Pembicaraan

Penjelasan : Klien masih mampu menjawab pertanyaan perawat dengan lambat namun dapat dipahami

c. Aktivitas Motorik

Penjelasan : Klien terlihat sedikit gelisah

d. Suasana perasaan

Penjelasan : Klien merasa dibuang oleh keluarganya dan merasa minder dengan orang lain karena di rawat diyayasan pemenang jiwa

Masalah keperawatan : Harga Diri Rendah 
e. Suasana perasaan

Penjelasan : Klien merasa dibuang oleh keluarganya dan merasa minder dengan orang lain karena di rawat diyayasan pemenang jiwa

Masalah keperawatan : Harga Diri Rendah

f. Afek

Penjelasan :Afek klien labil, mudah emosi, mudah marah.

Masalah keperawatan $\quad$ :Risiko perilaku kekerasan

g. Interaksi selama wawancara

Penjelasan : Klien kooperatif, ada kontak mata pada lawan

bicara, mudah tersinggung dalam setiap interaksi.

h. Persepsi

Penjelasan : Tidak mendengar suara-suara aneh

i. Proses Pikir

Penjelasan : Klien mampu menjawab apa yang ditanya dengan baik.

j. Isi piker

Penjelasan : Klien dapat mengontrol isi pikirnya,klien tidak mengalami gangguan isi pikir dan tidak ada waham. Klien tidak

k. Tingkat kesadaran

Penjelasan : Klien tidak mengalami gangguan orientasi, klien mengenali waktu, orang dan tempat.

1. Memori

Penjelasan : Klien mampu menceritakan kejadian di masa lalu dan yang baru terjadi.

m. Tingkat konsentrasi berhitung

Penjelasan : Klien mampu berkonsentrasi dalam perhitungan sederhana tanpa bantuan orang lain.

n. Kemampuan penilaian

Penjelasan : Klien dapat membedakan hal yang baik dan yang buruk.

o. Daya tilik diri

Penjelasan : Klien tidak mengingkari penyakit yang diderita, klien mengetahui bahwa dia sering marah. 


\subsection{Mekanisme Koping}

Klien mengalami mekanisme koping adaptif yaitu klien dapat berbicara baik dengan orang lain dan berkooperatif.

\section{7 .Masalah Psikososial dan Lingkungan}

Klien mengatakan sulit percya sama orang lain karena takut ditupi lagi sama orang disekelilingnya.

\subsection{Pengetahuan Kurang Tentang}

Klien tidak mengetahui tentang gangguan jiwa yang di alaminya, pasien mengatakan jika sedang emosi akan melampiaskannya pada dinding kamar. Masalah Keperawatan : Risiko Perilaku Kekerasan.

\subsection{Aspek Medik}

Diagnosa Medik :

a. Risiko Perilaku Kekerasan

b. Perilaku kekerasan

Terapi Medik: Pemberian/minum obat kepada pasien secara teratur.
a. Risperidon (RSP) tablet $2 \mathrm{mg} 2 \times 1$.
b. Klozapin $25 \mathrm{mg} 2 \times 1$ 


\subsection{Analisa Data}

\begin{tabular}{|c|c|c|}
\hline No & Data & masalah \\
\hline 1. & $\begin{array}{l}\text { DS:Klien mengatakan dirawat karena } \\
\text { mengamuk tidak jelas ,sering } \\
\text { melamun dan tinggal dijalan } \\
\text { DO: } \\
\text { - Pembicaraan : Cara bicara klien } \\
\text { pelan dan lambat, intonasi biasa } \\
\text { dan jelas } \\
\text { - Aktifitas motorik : Klien tampak } \\
\text { lesu, namun dapat membantu } \\
\text { aktivitas ruangan seperti } \\
\text { menyiapkan makan, } \\
\text { membersihkan ruangan setelah } \\
\text { makan, mengambil linen. } \\
\text { Alam Perasaan : Klien tampak } \\
\text { sedih Afek : datar, Klien tampak } \\
\text { tenang dan kooperatif. } \\
\text { Interaksi s elama wawancara } \\
\text { Klien kooperatif saat diajak } \\
\text { bicara, selalu memandang lawan } \\
\text { bicara, tak tampak marah. }\end{array}$ & $\begin{array}{l}\text { Risiiko perilaku } \\
\text { kekerasan }\end{array}$ \\
\hline 2. & $\begin{array}{l}\text { DS: Klien mengatakan merasa malu } \\
\text { dengan keadaannya saat ini dan ingin } \\
\text { kembali kerumah. } \\
\text { DO: } \\
\text { - Pembicaraan : Cara bicara Klien } \\
\text { pelan dan lambat, intonasi biasa } \\
\text { dan jelas bicara lambat, tampak } \\
\text { lesu, alam perasaan sedih }\end{array}$ & $\begin{array}{l}\text { Gangguan konsep } \\
\text { diri: Harga diri } \\
\text { rendah }\end{array}$ \\
\hline 3. & $\begin{array}{l}\text { DS : } \\
\text { Klien mengatakan bahwa ia adalah } \\
\text { artis, yang tidak sesuai dengan }\end{array}$ & $\begin{array}{l}\text { Gangguan } \text { Proses } \\
\text { Pikir : Waham }\end{array}$ \\
\hline
\end{tabular}




\begin{tabular}{|l|l|}
\hline kenyataan & (Waham \\
DO : & Kebesaran) \\
Klien tampak bingung, banyak bicara & \\
dan hiperaktif & \\
\hline
\end{tabular}

3.11. Masalah Keperawatan:

a. Risiko perilaku kekerasan

b. Gangguan konsep diri : Harga diri rendah

\subsection{Pohon Masalah}

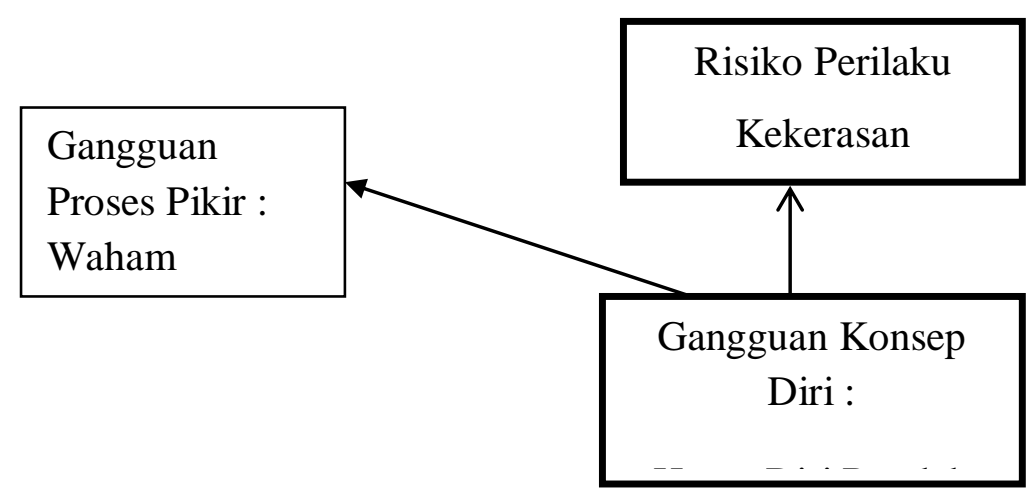

\subsection{Prioritas Masalah Keperawatan}

1.Risiko Perilaku Kekerasan

2.Gangguan Konsep Diri: Harga Diri Rendah

3.Gangguan Proses Pikir : Waham 
3.14.Intervensi Keperawatan

\begin{tabular}{|c|c|c|c|}
\hline $\begin{array}{l}\text { Diagnosa } \\
\text { Keperawatan }\end{array}$ & Tujuan & Kriteria Hasil & Intervensi \\
\hline $\begin{array}{l}\text { Risiko } \\
\text { Perilaku } \\
\text { Kekerasan. }\end{array}$ & $\begin{array}{lr}\text { Klien dapat membina } \\
\text { hubungan } & \text { saling } \\
\text { percaya. } & \end{array}$ & $\begin{array}{l}\text { Ketika di evaluasi } \\
\text { pasien mampu } \\
\text { membalas salam, } \\
\text { tersenyum, ada } \\
\text { kontak mata serta } \\
\text { menyediakan } \\
\text { waktu untuk } \\
\text { kunjungan } \\
\text { berikutnya }\end{array}$ & $\begin{array}{l}\text {.1.Membina hubungan } \\
\text { saling percaya dengan cara } \\
\text { menjelaskan maksud dan } \\
\text { tujuan interaksi,jelaskan } \\
\text { tentang kontrak yang akan } \\
\text { di buat, beri rasa aman dan } \\
\text { sikap empati. } \\
\text { 2.Diskusi bersama Klien } \\
\text { tentang Perilaku } \\
\text { kekerasan, } \\
\text { penyebab,tanda dan } \\
\text { gejala perilaku yang } \\
\text { muncul dan Akibat dari } \\
\text { perilaku tersebut }\end{array}$ \\
\hline $\begin{array}{l}\text { Risiko } \\
\text { Perilaku } \\
\text { Kekerasan }\end{array}$ & $\begin{array}{l}\text { Klien dapat } \\
\text { mengendalikan } \\
\text { mengendalikan } \\
\text { perilaku kekerasan } \\
\text { dengan cara relaksi } \\
\text { nafas dalam } \\
\text { dan pukul } \\
\text { bantal/kasur }\end{array}$ & $\begin{array}{l}\text { Klien mampu } \\
\text { menyebutan dan } \\
\text { menrekomendasik } \\
\text { an cara mengontrol } \\
\text { perilaku kekerasan } \\
\text { dengan ara } \\
\text { relaksasi nafas } \\
\text { dalam dan pukul } \\
\text { bantal. }\end{array}$ & $\begin{array}{l}\text { Sp1: } \\
\text { Latihan Melakukan cara } \\
\text { mengontrol amarah : } \\
\text { a.Anjurkan teknik relaksasi } \\
\text { nafas dalam. } \\
\text { b.Pukul bantal. }\end{array}$ \\
\hline $\begin{array}{l}\text { Risiko } \\
\text { Perilaku } \\
\text { Kkekerasan }\end{array}$ & $\begin{array}{l}\text { Klien dapat } \\
\text { mengendalikan } \\
\text { perilaku kekerasan } \\
\text { dengan minum obat } \\
\text { secara teratur }\end{array}$ & $\begin{array}{l}\text { Klien mampu } \\
\text { mengendalikan } \\
\text { perilaku } \\
\text { dengan minum } \\
\text { obat } \\
\text { Risperidon (RSP) } \\
\text { dengan teratur. }\end{array}$ & $\begin{array}{l}\text { Sp2 : } \\
\text { a.Bantu klien mengontrol } \\
\text { perilaku Kekerasan } \\
\text { dengan cara minum } \\
\text { obat secara teratur 2x } \\
\text { 1hari }\end{array}$ \\
\hline
\end{tabular}




\begin{tabular}{|c|c|c|c|}
\hline $\begin{array}{l}\text { Resiko } \\
\text { Perilaku } \\
\text { Kekeraasan }\end{array}$ & $\begin{array}{l}\text { Klien paham dan } \\
\text { mampu mengendalikan } \\
\text { risiko perilaku } \\
\text { kekerasan dengan cara } \\
\text { bicara dengan baik. }\end{array}$ & $\begin{array}{l}\text { Klien paham dan } \\
\text { mampu } \\
\text { menyampaikan } \\
\text { amarah dengan } \\
\text { cara berbicara } \\
\text { dengan baik. }\end{array}$ & $\begin{array}{l}\text { Sp3 : Bantu klien } \\
\text { mengontrol risiko perilaku } \\
\text { kekerasan } \\
\text { Dengan menganjurkan } \\
\text { klien berbicarayang baik } \\
\text { bila sedang dengan tiga } \\
\text { cara : } \\
\text { b. Meminta sesuatu } \\
\text { dengan baik tanpa } \\
\text { marah. sesuatu } \\
\text { c. Menolak } \\
\text { dengan baik. } \\
\text { Mengungkapkan } \\
\text { perasaan kesal. }\end{array}$ \\
\hline $\begin{array}{l}\text { Risiko } \\
\text { Perilaku } \\
\text { Kkekerasan }\end{array}$ & $\begin{array}{l}\text { Klien paham dan } \\
\text { mampu } \\
\text { mengendalikan risiko } \\
\text { perilaku kekerasan } \\
\text { denganmcara } \\
\text { mempraktikan cara } \\
\text { spritual. }\end{array}$ & $\begin{array}{l}\text { Klien paham dan } \\
\text { mamu } \\
\text { mengendalikan } \\
\text { risiko perilaku } \\
\text { kekerasan dengna } \\
\text { cara beribadah } \\
\text { sesuai agama yang di } \\
\text { anut Klien. }\end{array}$ & $\begin{array}{l}\text { Sp4: } \\
\text { Klien risiko perilaku } \\
\text { kekerasan Diskusikan } \\
\text { bersama klien cara } \\
\text { mengendalikan perilaku } \\
\text { kekerasan dengan cara } \\
\text { beribadah. }\end{array}$ \\
\hline $\begin{array}{l}\text { Gangguan } \\
\text { Konsep Diri } \\
\text { : Harga Diri } \\
\text { Rendah }\end{array}$ & $\begin{array}{l}\text { 1. Klien dapat } \\
\text { mengidentifi } \\
\text { kasi aspek } \\
\text { positif dan } \\
\text { kemampuan } \\
\text { yang } \\
\text { dimiliki } \\
\text { 2. Klien } \\
\text { dapat menilai } \\
\text { kemampuan yang } \\
\text { dimiliki } \\
\text { untuk } \\
\text { dilaksanakan }\end{array}$ & 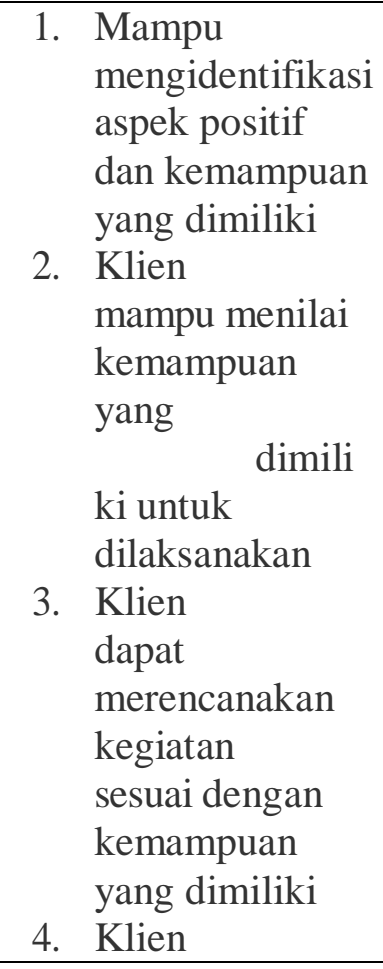 & $\begin{array}{l}\text { Sp 1: } \\
\text { Mengidentifikasi } \\
\text { kemampuan dan aspek } \\
\text { positif yang dimiliki } \\
\text { pasien } \\
\text { Sp 2: } \\
\text { a. } \text { Menilai } \\
\quad \text { kemampuan } \\
\quad \text { yang dapat } \\
\text { digunakan } \\
\text { b. } \text { Menetapkan atau } \\
\text { memilih } \\
\quad \text { kegiatan sesuai } \\
\text { kemampuan } \\
\text { c. Melatih } \\
\text { kegiatan sesuai } \\
\text { kemampuan } \\
\text { yang dipilih }\end{array}$ \\
\hline
\end{tabular}




\begin{tabular}{|c|c|c|c|c|}
\hline & 3. & $\begin{array}{l}\text { Klien } \\
\text { dapat } \\
\text { merencanakan } \\
\text { kegiatan } \\
\text { sesuai dengan } \\
\text { kemampuan yang } \\
\text { dimiliki } \\
\text { Klien } \\
\text { dapat melakukan } \\
\text { kegiatan } \\
\text { sesuai } \\
\text { rencana } \\
\text { yang dibuat }\end{array}$ & $\begin{array}{l}\text { dapat } \\
\text { melakukan } \\
\text { kegiatan } \\
\text { sesuai rencana } \\
\text { yang dibuat }\end{array}$ & \\
\hline
\end{tabular}

\subsection{IMPLEMENTASI DAN EVALUASI}

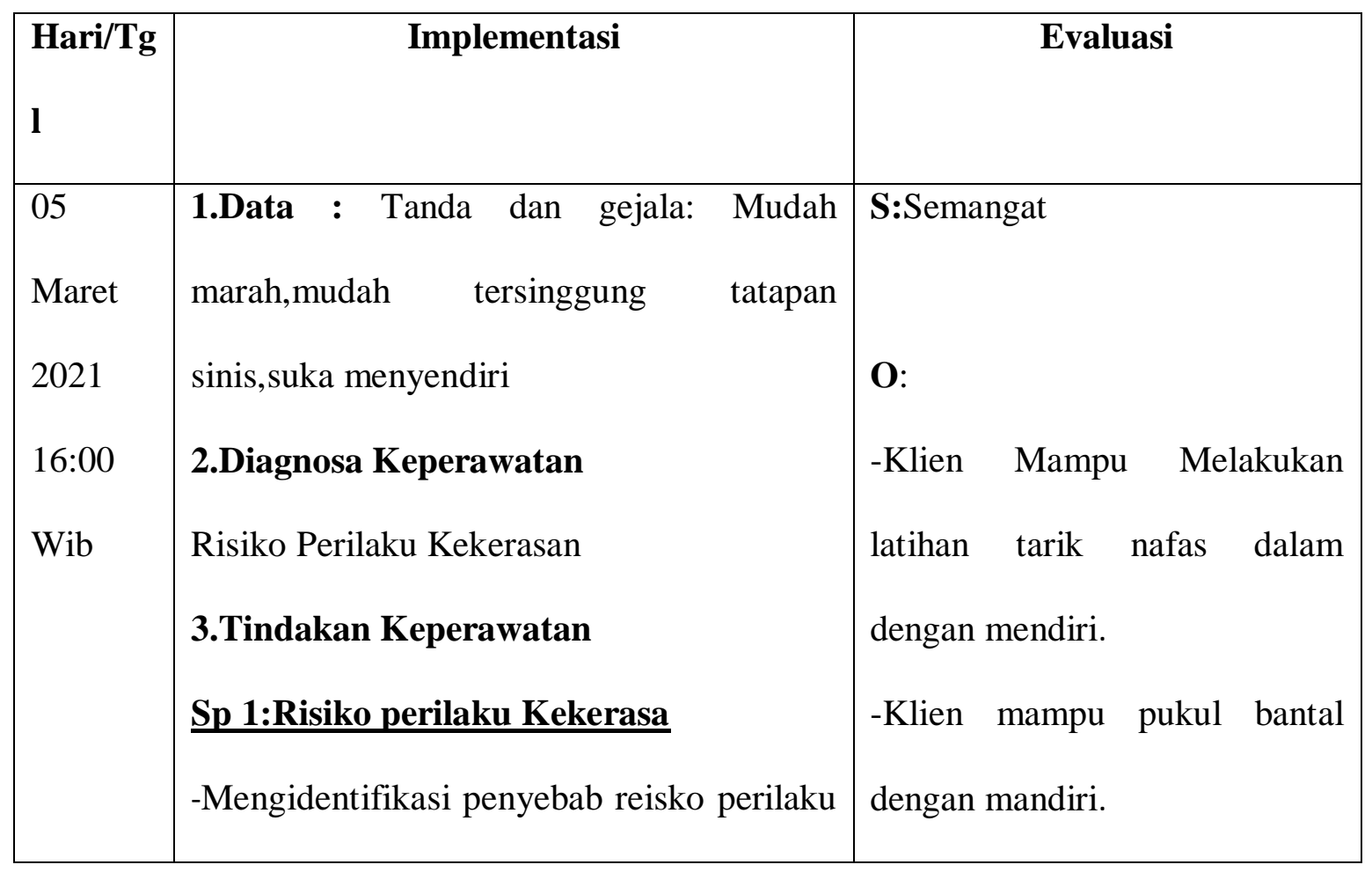




\begin{tabular}{|c|c|c|}
\hline & $\begin{array}{l}\text { kekerasan yaitu jika kemauan klien tidak } \\
\text { diturutin. } \\
\text { - Mengidentifikasi tanda dan gejala risiko } \\
\text { perilaku kekerasan yaitu Klien marah, } \\
\text { mengamuk tanpa alasan yang jelas, } \\
\text { merusak barang-barang dan cenderung } \\
\text { melukai orang lain. } \\
\text { - Menyebutkan cara mengontrol risiko } \\
\text { perilaku kekerasan dengan latihan fisik : } \\
\text { Tarik nafas dalam dan pukul bantal kasur. } \\
\text { - Membantu Klien latihan tarik nafas dalam } \\
\text { dan pukul bantal. } \\
\text { 4.RTL } \\
\text { Sp2 : Risiko perilaku kekerasan. } \\
\text { - Mengontrol risiko perilaku kekerasan } \\
\text { - Komunikasi secara verbal : Asertif/Bicara } \\
\text { dengan minum obat secara teratur. }\end{array}$ & $\begin{array}{l}\text { A : Risiko Perilaku Kekerasan } \\
\text { P: Latihan fisik : } \\
\text { - Tarik nafas dalam } 3 \mathrm{x} \text { tarik } \\
\text { nafas 1x/hari. } \\
\text { - Pukul kasur bantal 1x/hari. }\end{array}$ \\
\hline 08 & 1.Data : Tanda dan gejala : mudah marah- & S: Semangat \\
\hline Maret & $\begin{array}{l}\text { marah, mudah tersinggung, tatapan sinis, } \\
\text { merasa tidak dihargai. Kemampuan }\end{array}$ & $\begin{array}{l}\text { O : } \\
\text { - Klien mampu melakukan tarik }\end{array}$ \\
\hline & membaca & nafas dalam dengan mandiri. \\
\hline 10:00 & 2. Diagnosa keperawatan & - Klien mampu pukul bantas \\
\hline Wib & Risiko perilaku kekerasan & secara mandiri. \\
\hline
\end{tabular}




\begin{tabular}{|c|c|c|}
\hline & $\begin{array}{l}\text { 3.Tindakan keperawatan } \\
\text { Sp2 : Risiko Perilaku Kekerasan. } \\
\text { a. Mengevaluasi kemampuan pasien tarik } \\
\text { nafas dalam dan pukul kasur } \\
\text { b. Memberikan informasi tentang } \\
\text { pengguanaan obat } \\
\text { Sp3 : Risiko Perilaku Kekerasan. } \\
\text { a.Mengevaluasi kemampuan pasien } \\
\text { untuk tarik nafas dalam dan pukul } \\
\text { bantal kasur. } \\
\text { b.Minum obat } \\
\text { c.Komunikasi secara verbal : } \\
\text { asertif/bicara baik-baik. } \\
\text { 4. RTL : } \\
\text { Sp4 : Risiko Perilaku Kekerasan. } \\
\text { Spritual : Beribadah. }\end{array}$ & $\begin{array}{l}\text { - Klien mampu mengontrol } \\
\text { amarah dengan minum obat } \\
\text { secara teratur dengan bantuan } \\
\text { pengawas di yayasan pememng } \\
\text { jiwa sumatera } \\
\text {-Klien mampu melakukan } \\
\text { komunikasi secara verbal : } \\
\text { asertif/bicara baik-baik dengan } \\
\text { motivasi yang diberikan kepada } \\
\text { klien } \\
\text { A : Risiko Perilaku Kekerasan } \\
\text { (+). } \\
\text { P : - Latihan tarik nafas dalam } 3 \\
\text { x,1x/hari. } \\
\text { - Latihan pukul bantal 1x/hari. } \\
\text { - Minum Obat } \\
\text { - Klien melakukan komunikasi } \\
\text { secara verbal : asertif/bicara } \\
\text { baik-baik. }\end{array}$ \\
\hline Maret & $\begin{array}{l}\text { 1.Data: } \\
\text { Tanda dan gejala : mudah marah-marah, } \\
\text { mudah tersinggung, tatapan sinis, merasa } \\
\text { tidak dihargai. Kemampuan yang dimiliki } \\
\text { membaca buku. } \\
\text { 2. Diagnosa Keperawatan }\end{array}$ & $\begin{array}{l}\text { O : }- \text { Klien mampu } \\
\text { melaksanakan kegiatan ibadah } \\
\text { dengan baik, misalnya berdoa } \\
\text { dan mengikuti kegiatan ibadah }\end{array}$ \\
\hline
\end{tabular}




\begin{tabular}{|c|c|c|}
\hline & $\begin{array}{l}\text { - Risiko perilaku kekerasan. } \\
\text { 3. Tindakan Keperawatan. } \\
\text { Sp4 : Risiko Perilaku Kekerasan } \\
\text { - Mengevaluasi kemampuan Klien dalam } \\
\text { tarik nafas dalam dan pukul bantal kasur, } \\
\text { minum obat secara teratur dan berbicara } \\
\text { baik-baik. } \\
\text { - Melatih Klien untuk melakukan kegiatan } \\
\text { spritual yang sudah diatur. } \\
\text { 4.RTL : } \\
\text { Risiko perilaku kekerasan : Follow up } \\
\text { evaluasi Sp 1-4 Risiko Perilaku Kekerasan. }\end{array}$ & $\begin{array}{l}\text { di dalam yayasan. } \\
\text { A : Perilaku Kekerasan (+). } \\
\text { P : - Latihan tarik nafas dalam } \\
\text { dan pukul kasur bantal 2x/hari. } \\
\text { - Minum obat. } \\
\text {-Latihan } \\
\text { komunikasi secara verbal : } \\
\text { asertif/bicara baik-baik. } \\
\text { Latihan Klien } \\
\text { melaksakan kegiatan beribada } \\
\text { seperti berdoa. }\end{array}$ \\
\hline $\begin{array}{l}\text { Maret } \\
2021 \\
10: 00\end{array}$ & $\begin{array}{l}\text { 1. Data : } \\
\text { Tanda dan gejala : Hilang } \\
\text { kepercayaan diri, merasa gagal } \\
\text { karena tidak mampu mencapai } \\
\text { keinginan sesuai ideal diri, } \\
\text { perasaan tidak berharga, tidak } \\
\text { berarti dan rendah diri yang } \\
\text { berkepanjangan } \\
\text { 2. Diagnosa Keperawatan } \\
\text { Harga Diri Rendah } \\
\text { 3. Tindakan keperawatan: } \\
\text { Sp } 1 \text { Harga Diri Rendah: } \\
\text { Mengidentifikasi kemampuan dan } \\
\text { aspek positif yang dimiliki pasien }\end{array}$ & $\begin{array}{l}\text { S: Bersemangat } \\
\mathbf{O}: \text { Klien mampu } \\
\\
\text { Mengidentifikasi aspek } \\
\text { positif yang dimiliki } \\
\text { pasien yaitu berdoa dan } \\
\text { bersyukur. }\end{array}$ \\
\hline & & \\
\hline
\end{tabular}




\begin{tabular}{|c|c|c|}
\hline & $\begin{array}{l}\text { Sp2 Harga Diri Rendah: } \\
\text { a. Menilai kemampuan yang } \\
\text { dapat digunakan } \\
\text { b. Menetapkan atau memilih } \\
\text { kegiatan sesuai kemampuan } \\
\text { c. Melatih kegiatan sesuai kemampuan } \\
\text { yang dipilih } 1\end{array}$ & \\
\hline $\begin{array}{l}18 \\
\text { Maret } \\
2021 \\
10: 00 \\
\text { Wib }\end{array}$ & $\begin{array}{l}\text { 1. Data: } \\
\text { Tanda dan gejala : Hilang } \\
\text { kepercayaan diri, merasa gagal } \\
\text { karena tidak mampu mencapai } \\
\text { keinginan sesuai ideal diri, } \\
\text { perasaan tidak berharga, tidak } \\
\text { berarti dan rendah diri yang } \\
\text { berkepanjangan } \\
\text { 2. Diagnosa Keperawatan } \\
\text { Harga Diri Rendah } \\
\text { 3. Tindakan keperawatan: } \\
\text { Sp 2 Harga Diri Rendah: } \\
\text { a. Menilai kemampuan yang } \\
\text { dapat digunakan } \\
\text { b. Menetapkan atau memilih } \\
\text { kegiatan sesuai kemampuan } \\
\text { c. Melatih kegiatan sesuai } \\
\text { kemampuan yang dipilih } 1 \\
\text { yang dipilih } 2 \\
\text { RTL: Melatih kegiatan sesuai kemampuan }\end{array}$ & 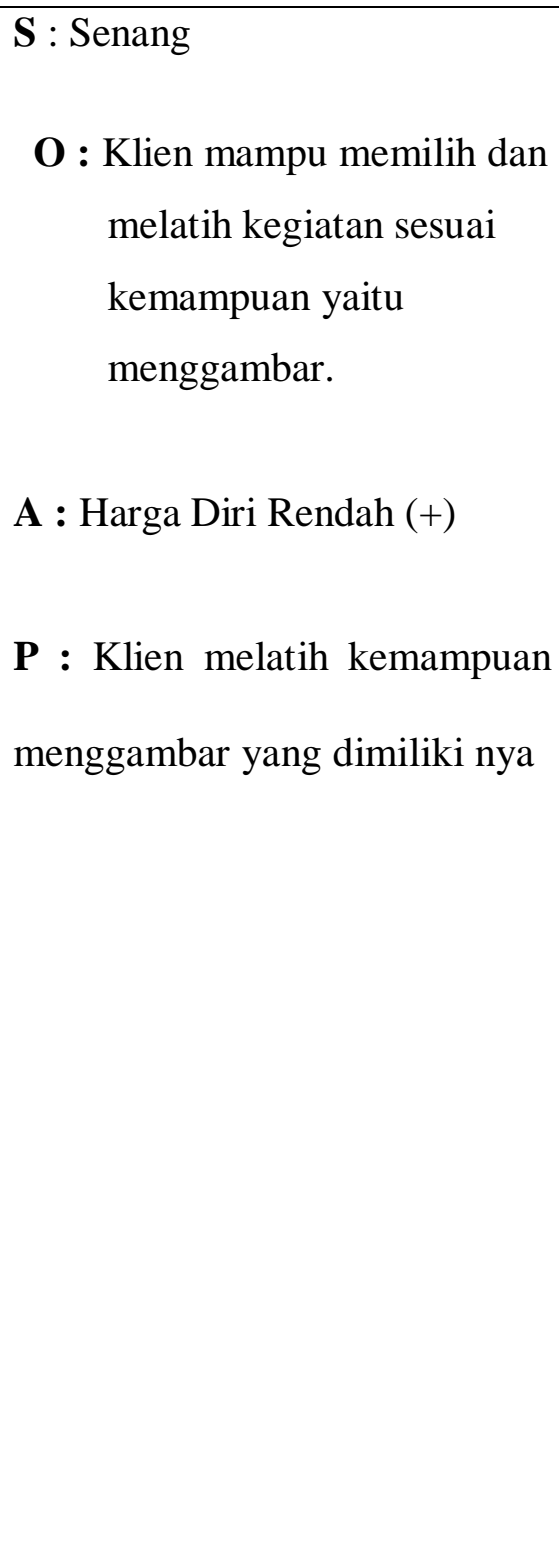 \\
\hline $\begin{array}{l}19 \\
\text { Maret } \\
2021\end{array}$ & $\begin{array}{l}\text { 1. Data: } \\
\text { Tanda dan gejala : Hilang kepercayaan diri, } \\
\text { merasa gagal karena tidak mampu } \\
\text { mencapai keinginan sesuai ideal diri, }\end{array}$ & $\begin{array}{l}\text { S: Senang } \\
\text { O : } \\
\text { Klien mampu melatih } \\
\text { kegiatan sesuai } \\
\text { kemampuan yaitu } \\
\text { menbersihkan }\end{array}$ \\
\hline
\end{tabular}




\begin{tabular}{|c|c|c|}
\hline Wib & $\begin{array}{l}\text { perasaan tidak berharga, tidak berarti dan } \\
\text { rendah diri yang berkepanjangan } \\
\text { 2. Diagnosa Keperawatan } \\
\text { Harga Diri Rendah } \\
\text { 3. Tindakan keperawatan: } \\
\text { Sp 3 Harga Diri Rendah: } \\
\text { Melatih kegiatan sesuai } \\
\text { kemampuan yang dipilih } 2 \\
\text { 4. RTL: } \\
\text { Sp : Melatih kegiatan sesuai kemampuan } \\
\text { yang dipilih } 3\end{array}$ & $\begin{array}{l}\text { perkarangan yayasan. } \\
\text { A : Harga Diri Rendah (+) } \\
\text { P : } \\
\text {-Berdoa,Mengikuti ibadah } \\
\text {-Mencuci piring } \\
\text {-Membakar sampah }\end{array}$ \\
\hline $\begin{array}{l}\text { Maret } \\
2021 \\
10.00\end{array}$ & 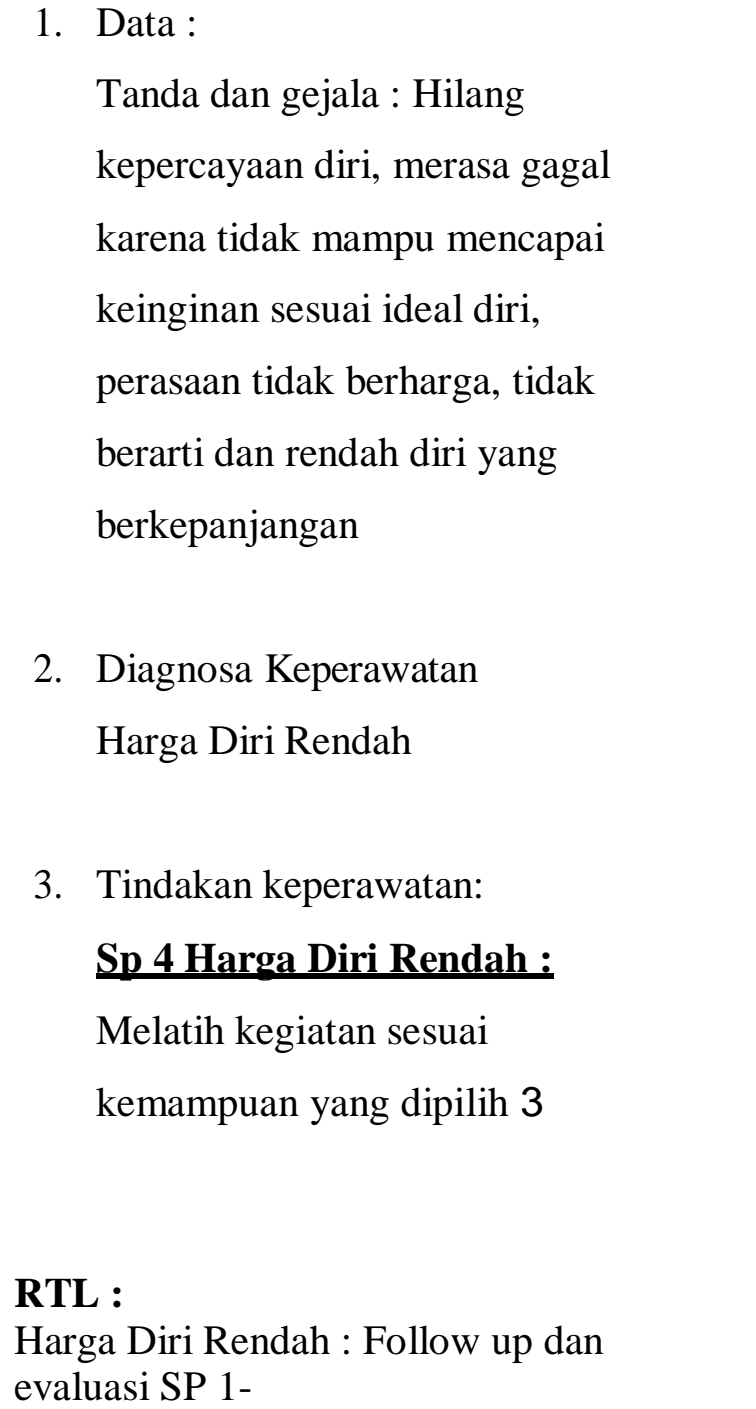 & $\begin{array}{l}\text { S : Senang } \\
\text { O : Melatih kegiatan sesuai } \\
\quad \text { kemampuan yang dipilih } \\
\quad \text { yaitu menyapu rumah } \\
\text { A : Harga diri rendah (+) } \\
\text { P : } \\
\text {-Berdoa, } \\
\text { ibadah } \\
\text {-Menyuci piring } \\
\text {-Menyapu Halaman } \\
\text {-Membakar sampah }\end{array}$ \\
\hline
\end{tabular}




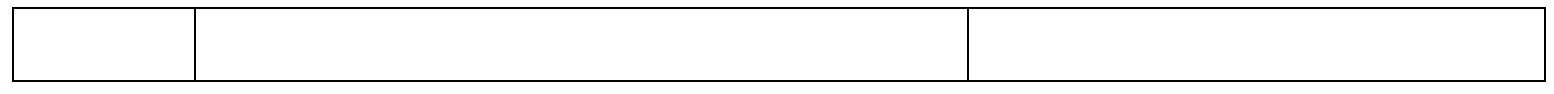

\section{BAB 4 \\ PEMBAHASAN}

Setelah penulis melaksanakan asuhan keperawat kepada Tn. B dengan gangguan Risiko Perilaku Kekerasan di Yayasan pemenang jiwa sumatra utara, maka penulis pada BAB ini akan membahasan kesenjangan antara teoritis dengan tinjauan kasus. Pembahasan dimulai melalui tahapan proses keperawatan yaitu pengkajian, diagnosa keparawatan, perencanaan, pelaksanaan dan evaluasi.

\subsection{Pengkajian}

Selama pengkajian dilakukan pengumpulan data dari beberapa sumber yaitu dari pasien dan pengawas yayasan. Mahasiswa mendapat sedikit kesulitan dalam mmenyimpulkan data kerena keluarga pasien jarang mengkunjungi pasien di yayasan pemenang jiwa. Maka mahasiwa melakukan pendekatan pada pasien melalui komunikasi terapeutik yang lebih terbuka membantu pasien untuk memecahkan perasaannya dan juga melakukan observasi kepada pasien. Ada pun upaya tersebut yaitu :

a. Melakukan pendekatan dan membina hubungan saling percaya diri pada pasien agar pasien lebih terbuka dan lebih percaya dengan menggunakan perasaan.

b. Mengadakan pengkajian pasien dengan wawancara dan tidak menemukan kesenjangan karena di temukan hal sama seperti diteori bahwasanya Perilaku kekerasan merupakan respon maladaptif dari kemarahan, hasil dari kemarahan yang ekstrim ataupun panik. Perilaku kekerasan yang timbul pada klien skizofrenia diawali dengan adanya perasaan tidak berharga, takut,dan ditolak oleh lingkungan sehingga individu akan menyingkir dari hubungan interpersonal dengan oran lain (Pardede, Keliat \& Yulia, 2015).

\subsection{Diagnosa Keperawatan}

Diagnosis keperawatan ialah identifikasi atau penilaian terhadap pola respons klien baik actual maupun potensial dan merupakan dasar pemilihan intervensi dalam mencapai tujuan yang telah di tetapkan oleh perawat yang bertanggung jawab. (Muhith, 2015., Stuart 2016. ) Data-data yang mendukung analisa data menurut (Keliat, 2015) :

1.Resiko perilaku Kekerasan

2.Harga Diri Rendah 


\subsection{Tahap perencanaan}

Perencanaan dalam proses keperawatan lebih di kenal dengan asuhan keperawatan yang merupakan tahap selanjutnya setelah pengkajian dan penentuan diagnosa keperawatan. Pada tahap perencanaan mahasiswa hanya menyusun rencan tindakan keperawatan Risiko Perilaku Kekerasan dan Perilaku Kekerasan. Pada tahap ini antara tinjauan teoritis dan tinjauan kasus tidak ada kesenjangan sehingga mahasiswa dapat melaksanakan tindakan seoptimal mungkin di dukung dengan seringnya bimbingan dengan pembimbing. Secara teoritis digunakan secara strategi pertemua sesuai dengan diagnosa keperawatan yang muncul saat pengkajian. Adapun upaya yang digunakan mahasiswa ialah :

\section{Risiko Perilaku Kekerasan}

a. Mengidentifikasikan isi Risiko Perilaku Kekerasan.

b. Mengidentifikasikan waktu terjadi Risiko Perilaku Kekerasan.

c. Mengidentifikasikan situasi pencetus Risiko Perilaku Kekerasan.

d. Mengidentifikasikan respon terhadap Risiko Perilaku Kekerasan.

e. Membantu pasien mempraktekkan latihan cara mengontrol Risiko Perilaku Kekerasan dengan tarik nafas dalam dan pukul bantal.

f. Menjelaskan cara mengontrol Perilaku Kekerasan dengan minum obat secara teratur.

g. Melatih pasien mengotrol Risiko Perilaku Kekerasan dengan berbicara baikbaik dengan orang lain dan spritual.

h. Mengevaluasi jadwal kegiatan harian pasien.

\subsection{Tahap Implementasi}

Pada tahap implementasi mahasiswa hanya mengatasi masalah keperawatan dengan diagnosa keperawatan Risiko perilaku Kekerasan/Perilaku Kekerasan karena masalah utama yang dialami pasien. Pada diagnosa keperawatan Risiko Perilaku Kekerasan/Perilaku Kekerasan strategi pertemuan ialah mengidentifikasi perilaku kekerasan, mengotrol perilaku kekerasan, dan cara tarik nafas dalam dan pukul bantal kasur. Strategi pertemuan yang kedua ialah anjurkan minum obat secara teratur, strategi pertemuan ketiga ialah latihan cara komunikasi secara verbal atau bicara baik-baik dan strategi terakhir pertemuan keempat yaitu spritual.

\subsection{Tahap Evaluasi}


Pada tinjauan kasus evaluasi yang dihasilkan adalah :

1. Klien sudah dapat mengontrol dan mengidentifikasi Risiko Perilaku Kekerasan.

2. Klien dapat mengendalikan Risiko Perilaku Kekerasan melalui latihan fisik.

3. Klien dapat mengendalikan Risiko Perilaku Kekerasan dengan cara pergi ke poli jiwa untuk mendapatkan minum obat.

4. Klien dapat mengendalikan Risiko Perilaku Kekerasan dengan berbicara baik-baik dengan orang lain.

5. Klien dapat mengendalikan RisikoPerilaku Kekerasan dengan melakukan spritual terjadwal 


\section{BAB 5 \\ PENUTUP}

\subsection{Kesimpulan}

Setelah menguraikan tentang proses keperawatan Tn.B dan disimpulkan bahwa pasien dapat mengontrol risiko perilaku kekerasan dengan terapi yang di ajarkan. Dimana pasien dapat melakukan tarik nafas dalam, memukul bantal secara mandiri untuk mengontrol amarahnya. Pasien juga minum obat secara teratur dan berbicara secara baik-baik jika ingin meminta sesuatu atau melakukan penolakan, hingga pasien dapat melakukan spritual sesuai ajaran agama yang dianut.

\subsection{Saran}

1. Bagi pasien dapat mengontrol emosi dengan menerapkan strategi pelaksanaan, mengontrol perilaku kekerasan dengan cara tarik nafas dalam dan pukul bantal kasur, minum obat secara teratur, latihan cara komunikasi secara verbal atau bicara baik-baik, dan spiritual untuk mendukung kelangsungan kesehatan pasien.

2. Bagi Yayasan Pemenang Jiwa hendaknya memberikan pelayanan kesehatan yang baik dan membuat suasana lingkungan menjadi lebih nyaman agar klien tidak melakukan risiko perilaku kekerasan. Usahakan memberikan saran, nasehat dan motivasi kepada klien agar klien mendapatkan cara tentang bagaimana mengontrol marah. 


\section{DAFTAR PUSTAKA}

1. Afnuhazi, R.(2015). Komunikasi Terapeutik Dalam Keperawatan Jiwa. Yogyakarta: Gosyen Publishing.

2. Anggit, M. A. (2021). Asuhan Keperawatan Jiwa Pada Pasien Dengan Resiko Perilaku Kekerasan (Doctoral dissertation, Universitas Kusuma HusadaSurakarta).http://eprints.ukh.ac.id/id/eprint/922/1/P17D\%20NASPUB \%2019\%2020\%20ANGGIT\%20MADHANI P17160.pdf

3. Dermawan, D \& Rusdi. (2015). Keperawatan Jiwa Dan Kerangka Kerja Asuhan Keperawatan Keperawatan Jiwa. Jogyakarta: Gosyen Publishing.

4. Hastuti, R. Y., Agustina, N., \& Widiyatmoko, W. (2019). Pengaruh restrain terhadap penurunan skore panss EC pada pasien skizofrenia dengan perilaku kekerasan. Jurnal Keperawatan Jiwa, 7(2), 135-144. https://jurnal.unimus.ac.id/index.php/JKJ/article/view/4907/pdf

5. Hasannah, S. U. (2019). Asuhan Keperawatan Jiwa pada Pasien Dengan Risiko Perilaku Kekerasan (Doctoral dissertation, STIKes Kusuma Husada Surakarta). http://eprints.ukh.ac.id/id/eprint/41

6. Keliat, B. A \&, Akemat. (2012). Keperawatan Jiwa: Terapi Aktivitas Kelompok. Jakarta:EGC

7. Keliat \& Akemat (2015), Model Praktik Keperawatan Profesional Jiwa, Jakarta: EGC

8. Kemenkes RI. (2019). Laporan Nasional Rist Kesehatan Dasar (riskesdas). Jakarta : Badan Penelitian dan Pengembangan Kesehatan.

9. Kemenkes RI. (2018). Laporan Nasional Rist Kesehatan Dasar (riskesdas). Jakarta: Badan Penelitian dan Pengembangan Kesehatan.

10. Mulia, D. D. P. B. (2020). Penatalaksanaan Secara Konstruktif Dengan Crossword

11. Puzzle Pasien Risiko Perilaku Kekerasan di RSJD dr. Arif Zainudin Surakarta. IJMS-Indonesian Journal on Medical Science, 7(2). http://ejournal.ijmsbm.org/index.php/ijms/article/view/246

12. Nursaly, E., \& Damaiyanti, M. (2018). Analisis Praktik Klinik Keperawatan pada Tn. E Resiko Perilaku Kekerasan dengan Intervensi Inovasi Terapi Berkebun dengan Polybag terhadap Tanda-Tanda Gejala Resiko Perilaku Kekerasan di RSJD Atma Husada Mahakam Samarinda. https://dspace.umkt.ac.id//handle/463.2017/571

13. Pardede, J. A. (2020). Family Burden Related to Coping when Treating Hallucination Patients. Jurnal Ilmu Keperawatan Jiwa, 3(4), 453-460. http://dx.doi.org/10.32584/jikj.v3i4.671

14. Pardede, J. A., Silitonga, E., \& Laia, G. E. H. (2020). The Effects of Cognitive Therapy on Changes in Symptoms of Hallucinations in Schizophrenic Patients. 
Indian Journal of Public Health, 11(10), 257. https://doi.org/10.37506/ijphrd.v11i10.11153

15. Pardede, J. A., Siregar, L. M., \& Hulu, E. P. (2020). Efektivitas Behaviour Therapy Terhadap Risiko Perilaku Kekerasan Pada Pasien Skizofrenia Di Rumah Sakit Jiwa Prof. Dr. Muhammad Ildrem Provsu Medan. Jurnal Mutiara Ners, 3(1), 8-14. http://114.7.97.221/index.php/NERS/article/view/1005

16. Pardede, J. A., Siregar, L. M., \& Halawa, M. (2020). Beban dengan Koping Keluarga Saat Merawat Pasien Skizofrenia yang Mengalami Perilaku Kekerasan. Jurnal Kesehatan, 11(2), 189-196. http://dx.doi.org/10.26630/jk.v11i2.1980

17. Pardede, J. A. (2020). Standar Asuhan Keperawatan Jiwa Dengan Masalah Risiko Perilaku Kekerasan. https://doi.org/10.31219/osf.io/we7zm

18. Prasetya, A. S. (2018). Efektifitas Jadual Aktivitas Sehari-Hari Terhadap Kemampuan Mengontrol Perilaku Kekerasan. Jurnal Kesehatan Panca Bhakti Lampung, 6(1), 18-29. http://ejournal.pancabhakti.ac.id/index.php/ikpbl/article/view/22

19. Putri,V.S., \& Fitrianti,S. (2018). Pengaruh Strategi Pelaksanaan Komunikasi Terapeutik Terhadap Resiko Perilaku Kkekerasan Pada Pasien Gangguan Jiwa DoRumah Sakit Jiwa Provinsi Jambi.Jurnal Akademika Baiturrahim Jambi,7(2),138-147. http://dx.doi.org/10.36565/jab.v7i2.77

20. Sutejo. (2017). Keperawatan Kesehatan Jiwa (Prinsip Dan Praktik Asuhan Keperawatan Jiwa), Yogyakarta : Pustaka Baru Press.

21. Suryanti, S., \& Ariani, D. (2018). Pengaruh Relaksasi Progresif Terhadap Penurunan Perilaku Kekerasan Pada Pasien Skizofrenia Di Rumah Sakit Jiwa Daerah Klaten. Interest: Jurnal Ilmu Kesehatan, 7(1), 67-74. http://www.jurnalinterest.com/index.php/int/article/view/74

22. Saputri, S. F. M \& Mar'atus, M. (2021). Asuhan Keperawatan Jiwa Dengan Resiko Perilaku Kekerasan. Skripsi, Universitas Kusuma Husada Surakarta.

23. Wardani, L. K., \& Sari, D. K. (2018). Analisa Kemampuan Mengontrol Marah ditinjau dari Penerapan REBT (Rational Emotive Behaviour Theraphy) pada Klien Skizofrenia di UPT Bina Laras Kras Kediri. STRADA Jurnal Ilmiah Kesehatan, 7(2), 57-61. https://sjik.org/index.php/sjik/article/view/173

24. WHO, (2019). Schizophrenia. Retrieved from https://www.who.int/newsroom/fact-sheets/detail/schizophrenia 
